The stratigraphic descriptions for Illinois define members that cover areas of the order of $50 \mathrm{~km}$ by $100 \mathrm{~km}\left(\mathrm{IO}^{3}-\mathrm{IO}^{4} \mathrm{~km}^{2}\right)$. Perhaps each member is to be associated with a single glacial advance or perhaps each bed represents an advance (a bed is a subdivision of a member). It would be very interesting to determine if the compositional variations within each member can be related to a similar pattern in the bedrock and other pre-existing deposits.

\title{
REFERENCES
}

Karrow, P. F. [ ${ }^{\mathrm{c}}{ }_{1976}$.] The texture, mineralogy, and petrography of North American tills. (In Legget, R. F., ed. Glacial till. An interdisciplinary study. [Ottawa], Royal Society of Canada in co-operation with the National Research Council of Canada, p. 83-98. (Royal Society of Canada Special Publications, No. 12.)

Willman, H. B., and Frye, J. C. 1970. Pleistocene stratigraphy of Illinois. Illinois State Geological Survey. Bulletin 94.

\section{PLOUGH MARKS IN THE WEDDELL SEA}

\author{
By Olav Orheim \\ (Norsk Polarinstitutt, Postboks I58, I330 Oslo, Norway)
}

\begin{abstract}
The 1976/77 Norwegian Antarctic Research Expedition carried out studies of the sea bed by side-scan sonar. The equipment was operated from the expedition vessel down to about $350 \mathrm{~m}$ depth by personnel from the Continental Shelf Institute, Trondheim. Various types of plough marks mostly ranging from 1o to $100 \mathrm{~m}$ in width were observed. These included several generations of crossing plough marks as well as plough marks with abrupt changes in trend reflecting changing iceberg motion. The investigations will be expanded during the $1978 / 79$ expedition to include towing at greater depths, and mapping of sea-bed morphology by mosaic towing patterns.
\end{abstract}

\section{DISCUSSION}

D. E. Thompson: What is the size of your side-scan swath before resolution is lost?

O. Orheim: Typically we were scanning from 50-10o $\mathrm{m}$ above the sea bed giving good resolution imagery of the bed over a $300 \mathrm{~m}$ wide swath to each side.

\section{ICE-SHEET EROSION-A RESULT OF MAXIMUM CONDITIONS?}

\author{
By D. E. Sugden \\ (Department of Geography, University of Aberdeen, Aberdeen AB9 2 UF, Scotland)
}

Abstract. Understanding the relationship between the morphology of former ice-sheet beds and glaciological processes is handicapped by the difficulty of establishing which stage of a cycle of ice-sheet growth and decay is responsible for most erosion. Discussions at this conference and in the literature display a variety of opinions, some favouring periods of icesheet build up, others periods of fluctuations, and still others steady-state maximum conditions. Here it is suggested that there is geomorphological evidence which points to the dominance of maximum conditions. 